\author{
Michał Kałdoński \\ Jacek Mizerka \\ michal.kaldonski@ae.poznan.pl \\ jacek.mizerka@ae.poznan.pl \\ Poznań University of Economics, Chair of Corporate Finance \\ al. Niepodległości 10 60-967 Poznań, Poland
}

\title{
POLITICIANS AND PRIVATE BENEFITS OF CONTROL
}

\begin{abstract}
The article discusses the identification and valuation of private benefits of control occurring when the State Treasury retains controlling interest in a company that is being privatized. The benefits are gained by politicians at the expense of the State Treasury and private investors. Using the case of a dispute between the State Treasury of the Republic of Poland and Eureko B.V. over the control of PZU, Poland's largest insurance company, we reduce the issue of control of a company to the selection of the ownership structure. To determine the value of private benefits of control, we suggest that the option-to-switch valuation model should be used.
\end{abstract}

JEL Classification: G12; G32; G34

Key words: Privatization; IPO; Value of Control; Real options

\section{Introduction}

Private benefits of control of company resources are one of the key issues dealt with by today's corporate-finance researchers, which is reflected in the subject literature. In particular, publications devoted to investor protection and its significance for financial market development lay special emphasis on the value of private benefits gained by the party in control of the company.

The most up-to-date research in this field suggests that private benefits of control account for $14 \%$ of the equity value ${ }^{1}$. However, the research concerns private companies. Relatively little of the subject literature is devoted to private benefits which can be gained if one owns shares in state-owned companies. The problem gains special significance in an economy undergoing transformation and finds its expression in the State Treasury's retention of shares

\footnotetext{
1 A. Dyck, L. Zingales, Private Benefits of Control: An International Comparison, "Journal of Finance" 2004, Vol. 59, pp. 537-600
} 
in companies which are being privatized. Apart from private investors, it is also politicians who can gain benefits of control.

Difficulties with the identification and measurement of the value of private benefits of control gained by politicians result from the nature of the phenomenon. So far, a complete catalogue of manifestations of private benefits of control has not been made. Financing election campaigns and buying people's votes are the most common forms of benefit derived by politicians. In the case of companies with the State Treasury's majority shareholding, these benefits are enjoyed at the expense of both the State Treasury and private investors. An example of minority shareholders expropriation is the case of Eureko B.V., which has shares in PZU, Poland's largest insurance company.

Using the example of Eureko B.V.'s investment in PZU, we demonstrate that the subject of the conflict between majority and minority shareholders can be reduced to the issue of ownership structure selection.

The article is divided into four sections. The first one presents the idea of private benefits of control. The second section is devoted to the discussion of manifestations and consequences of politicians' control of companies. In the third section we point to the possibility of treating the control of a company as the right to choose the ownership structure. Finally, we suggest applying the option approach to estimating the value of the right to choose the ownership structure.

\section{The idea of private benefits of control}

In the subject literature, the idea of private benefits of control is very often understood as the "psychological" value which shareholders attribute to the possession of power. Advocates of this view include Aghion and Bolton as well as Harris and Raviv ${ }^{2}$. Another, more palpable source of private benefits of control is perquisites. According to Jensen and Meckling, a manager possessing shares in a company can derive two types of benefits ${ }^{3}$. The first type of benefits, whose size is directly proportional to the shares possessed, results from an increased company value and has the form of dividends and capital gains. Benefits of the second type are various perquisites (luxurious offices, company cars, attractive personnel, prestige and respect among employees, etc.) to which only managers are entitled.

\footnotetext{
${ }^{2}$ P. Aghion, P. Bolton, An Incomplete Contract Approach to Financial Contracting , "Review of Economic Studies" 1992, Vol. 59, pp. 473-494 and M. Harris, A. Raviv, Corporate Governance: Voting Rights and Majority Rules, "Journal of Financial Economics" 1998, Vol. 20, pp. 203-235

${ }^{3}$ M.C. Jensen, W.H. Meckling, Theory of the firm: managerial behavior, agency costs and ownership structure, "Journal of Financial Economics" 1976, Vol. 3, pp. 305-360
} 
Exploiting company resources in order to obtain perquisites is a much more measurable way of gaining private benefits of control than running one's company "in one's own way". This does not mean, however, that it is the most significant way. Expropriation of minority shareholders by the party in control of the company can be carried out on a considerably larger scale and in a considerably more refined way ${ }^{4}$. According to Johnson, La-Porta, Lopezde-Silanes and Schleifer, we can distinguish two basic forms of tunneling. The first one consists in transferring company resources by means of self-dealing. This type of transaction covers both activities which are illegal by definition, such as theft or fraud, and activities which are ostensibly legal. The latter include the purchase or sale of products and assets at prices different from market prices, higher than "fair" transfer price, managers' remuneration, loan repayment guarantees or taking over the company's investment opportunities for one's own purposes. Another method of tunneling is transactions leading to dilution. The party in control increases its share through dilutive share issues, minority freeze-outs, insider trading, creeping acquisitions or other financial transactions which result in discrimination against minority shareholders.

The psychological aspect of private benefits of control is much more difficult to define, and thus to quantify. An example of such benefits, given by Demsetz and Lehn, is amenities enjoyed by sports club and media owners in the form of the ability to influence competition results or the public opinion ${ }^{5}$. Other authors point to social prestige, family traditions, the opportunity to promote one's relatives, i.e. issues connected with reputation broadly understood $^{6}$.

Taking into account all these considerations, it should be stated that private benefits of control can concern any situation in which a value, irrespective of its origin, is not shared among shareholders proportionally to the shares owned, but its only beneficiary is the party in control $^{7}$. At the same time, it should be noted that private benefits of control can take the form of pecuniary or non-pecuniary benefits. Differences among private benefits of control can concern the degree of their transferability. The basic kinds of private benefits of control are listed in Table 1.

\footnotetext{
${ }^{4}$ S. Johnson, R. La Porta, F. Lopez-de-Silanes, A. Shleifer, Tunneling, "American Economic Review”, 2000, Vol. 90, pp. 22-27

${ }^{5}$ H. Demsetz, K. Lehn, The Structure of Corporate Ownership: Causes and Consequences, "Journal of Political Economy "1985, Vol. 93, pp. 1155-1177

${ }^{6}$ M. Holmen, P. Hőgfeldt, A Law and Finance Analysis of Initial Public Offerings, "Stockholm School of Economics Working Paper" 2000

${ }^{7}$ A. Dyck, L. Zingales, Private Benefits of Control: An International Comparison, "Journal of Finance" 2004, Vol. 59, pp. 537-600
} 
Table 1 Basic kinds of private benefits of control

\begin{tabular}{|l|l|l|}
\hline $\begin{array}{l}\text { Degree of transferability / } \\
\text { Form }\end{array}$ & Pecuniary benefits & Non-pecuniary benefits \\
\hline High transferability & I. Self-dealing & III. Amenities \\
\hline Low transferability & II. Dilution of claims & IV. Reputation \\
\hline
\end{tabular}

Source: on the basis of O. Erhardt, E. Nowak, Private Benefits and Minority Shareholder Expropriation Empirical Evidence from IPOs of German Family-Owned Firm, “CFS Working Paper” 2001, Vol. 10.

The nature of private benefits of control makes it difficult, or even impossible, to measure them. This is reflected in the methods used in practice to measure private benefits of control. Two such methods can be found in the literature.

The first one has been put forward by Barclay and Holderness ${ }^{8}$. Its starting point is the assumption that the share price paid by the purchaser of controlling interest corresponds with the sum of the benefits he obtains in the form of a certain part of the cash flow generated by the company and private benefits of control. The first kind of benefits results from the possession of an adequate number of company shares, the other - from one's position. However, the market price of shares after control has been gained corresponds with a minority shareholder's share in the cash flow generated by the company when run by the new managers. The difference between the share price in a transaction leading to the acquisition of controlling interest and the market price quoted after the sale of a shareholding is announced determines the value of private benefits of control.

The second method of estimating the value of private benefits of control is based on the distinction between shares according to the number of voting rights. Rydquist, Zingales and Nenova argue that the value of private benefits of control corresponds with the difference between the prices of shares with different voting rights 9 .

It is pointed out in the literature that the two methods presented above are by no means perfect. Estimations of the value of private benefits of control made with the use of these methods do not take into account non-pecuniary benefits of control ${ }^{10}$.

\footnotetext{
8 M. Barclay, C. Holderness, Private Benefit of Control of Public Corporations, "Journal of Financial Economics" 1989, Vol. 25, pp. 71-395

${ }^{9}$ K. Rydqvist, Empirical Investigation of the Voting Premium, "Northwestern University Working Paper" 1987, Vol. 35, L. Zingales, The Value of the Voting Right: A Study of the Milan Stock Exchange Experience, "Review of Financial Studies" 1994, Vol. 7, pp. 125-148, L. Zingales, What Determines the Value of Corporate Votes, "Quarterly Journal of Economics" 1995, Vol. 110, pp. 1047-1073, T. Nenova, The Value of Corporate Votes and Control Benefits: A Cross-country Analysis, "NBER Working Paper" 2000

${ }^{10}$ A. Dyck, L. Zingales, op. cit.
} 
It should be emphasized that private benefits of control are by their nature difficult to identify and quantify. Otherwise, the possibility that minority shareholders will take legal action to assert their rights would mean these benefits might lose their private character. It is worth noting that - apart from private investors - it is also politicians that can derive private benefits of control of the company.

\section{Manifestations and consequences of politicians' control of companies}

The problem of politicians' control of companies becomes especially significant in the case of the privatization of state enterprises. The privatization of state enterprises has always been one of the major tasks facing the economies of Central and Eastern Europe. However, the process runs into various difficulties. One of them is caused by the unresolved issue of whether or not the State Treasury should retain shares in privatized companies, at least for a period of time ${ }^{11}$. The State Treasury's involvement is explained in various ways. Jelic, Briston and Aussenegg argue that the size of shareholdings in companies sold by the state is positively correlated with improvement in their long-term effectiveness ${ }^{12}$. Others, e.g. Perotti, perceive this as a positive phenomenon, interpreting it as a symptom of the state's involvement in the privatization programme and willingness to share political risk with entrepreneurs $^{13}$. Still others, e.g. Boycko, Shleifer and Vishny, do not see any benefits in privatized company shares being retained by the state, fearing the state's excessive interference in corporate management ${ }^{14}$.

According to Boycko, Shleifer and Vishny, there is a conflict of interests between managers and politicians. Because of potential political benefits, politicians allow companies to be overstaffed and to pay high wages. On the other hand, managers predicting the acquisition of some shares are interested in improving the company's effectiveness. Both sides of the conflict play a game of sorts over the size and costs of employment.

The authors illustrate the issue of politicians' control of companies with a model according to which the company determines labour spending $(E)$. It is also assumed that managers represent the interests of private shareholders. The participation of private owners

\footnotetext{
${ }^{11}$ I. Schindele, Theory of Privatization in Eastern Europe: Literature Review, "Fondazione Eni Enrico Mattei", 2003

${ }^{12}$ R. Jelic, R. Briston, W Aussenegg, The Choice of Privatization Method and the Financial Performance of Newly Privatized Firms in Transition Economies, "Journal of Business Finance and Accounting", 2003, Vol. 30 (7 and 8), pp. $905-940$

${ }^{13}$ E.C. Perotti, Credible Privatization, “American Economic Review”, 1995, Vol. 85, pp. 847-859

${ }^{14}$ A. Shleifer, R.W. Vishny, Polticians and Firms, "Quarterly Journal of Economics ”, 1994, Vol. 109, pp. 9951025 and M. Boycko, A. Shleifer, R.W. Vishny, A Theory of Privatization, "Economic Journal", 1996, Vol. 106, pp. 309-319
} 
in the company's profits amounts to $\alpha$, whereas the State Treasury's participation is $(1-\alpha)$. The interest of politicians who do not have shares comes down to receiving the employees' support in elections. To achieve this, they exert pressure on the company to increase labour spending. Politicians' marginal benefit of an extra dollar designed for remuneration equals $q$ $(q<1)$. Increased labour spending results in the company's lower profits. The possible occurrence of potential losses causes politicians to take into account the State Treasury's sanctions. The cost a politician pays because of the State Treasury's loss of a profit of the firm amounts to $m$. Since the politician cares more about his own income than the State Treasury's revenue, the values of $m$ are less than 1 . The compromise between the benefits and costs associated with excessively increased labour spending is expressed by the politician objective function $\left(U_{p}\right)$.

$$
U_{p}=q E-m(1-\alpha) E
$$

The manager (shareholder) objective function reflects only benefits from participation in the company's profits.

$$
U_{m}=-\alpha E
$$

A key role in the model is played by the entity in control of labour spending. In the case of companies with a dominant shareholding owned by the State Treasury, labour spending is determined by politicians. Politicians' propensity to increase remuneration is expressed by the following condition:

$$
m(1-\alpha)<q
$$

It follows from condition (3) that politicians' benefits per dollar of extra spending on labour are higher than the costs which the politicians suffer when the State Treasury consequently loses a revenue unit. Politicians' control of companies gives rise to a lower effectiveness of the economy, which benefits politicians at the expense of the State Treasury and the other shareholders. 
Excessive employment and higher wages are not the only source of politicians' benefits, which can also take the form of cheap loans given by state companies to political parties to finance election campaigns. Another method of winning peoples' votes is to influence decisions to locate company investment projects in economically unviable areas. People's votes can be bought by selling selected products (e.g. train tickets, food) at prices lower than the marginal production cost ${ }^{15}$.

It seems that politicians' intention to get benefits of control of a state-owned company can explain the case of PZU, Poland's largest insurance company. The history of PZU privatization dates back to 1999, when the Dutch insurance holding Eureko BV, owner of shareholdings in eight companies based in Europe, formed a consortium with Bank Millenium in order to acquire PZU shares. The consortium's investment, which consisted in acquiring $30 \%$ of PZU shares, was worth 700 million euros. The share purchase was made on the basis of the Polish government's decision and promise to privatize PZU in 2000 through an initial public offering at the Warsaw Stock Exchange. The initial public offering of PZU shares, the third and last stage of privatization, was decided in two agreements signed by Eureko and the State Treasury of the Republic of Poland. According to the privatization agreement, the Polish government's aim was to reduce the State Treasury's majority shareholding to the level of approximately $5 \%$. In the second stage of the privatization process, the Polish government gave $15 \%$ of PZU shares to PZU employees, leaving $55 \%$ of equity in the hands of the State Treasury. Eureko, on the other hand, bought $13 \%$ of shares, $10 \%$ of which came from Bank Millenium and the rest of them from employees. At present, Eureko owns less than $33 \%$ of PZU shares. There is a simultaneous dispute over the State Treasury's failure to fulfill its obligations to Eureko.

The subject of the dispute is the consequences of the Polish state's sudden about-turn at the end of 2001 and the beginning of 2002 on the matter of the PZU privatization strategy, on the basis of which Eureko decided to make an investment in Poland by initially purchasing a minority shareholding of $30 \%$ of PZU shares. Eureko's investment included not only rights resulting from the possession of a block of shares but also the right to take control of the company. The State Treasury undertook to sell another $21 \%$ of PZU shares to Eureko as part of the initial public offering.

At first glance, it would seem that the initially adopted strategy of PZU privatization was designed to maximize the State Treasury's revenue. According to Zingales, revenues from the

\footnotetext{
${ }^{15}$ A. Shleifer, R.W. Vishny, op. cit.
} 
sale of a company are the highest when control rights and cash-flow rights are sold separately. The optimum method of selling cash-flow rights is an initial public offering (IPO), while the best way of selling control rights is a direct transaction with a purchaser ${ }^{16}$.

As a result of the change in the PZU privatization strategy, the State Treasury still owns a majority stake in the company's equity. It is the State Treasury's right, therefore, to appoint the majority of managers in the company. However, such appointments are as a rule based on political considerations, whose aim is neither improvement in the work of PZU nor proper management of the company's activity. As each political party appoints its representatives, since 1999 PZU has had as many as seven chairmen of the board appointed by the State Treasury.

At present, Eureko demands to be sold the promised 21\% of PZU shares at 2001 prices and to be paid compensation, the level of which is estimated at approximately 1,500 million euros. A question arises, therefore, concerning the grounds for and the level of compensation. In the next part of the paper we are attempting to present the theoretical justification for the claim. We reduce the issue of possessing control of a company to the possession of the right to choose its ownership structure.

\section{The right to choose the ownership structure as an instance of private benefits of control}

A private company and a public company are two basic forms of corporate ownership structure. The choice of an ownership structure is a compromise between certain benefits and $\operatorname{costs}^{17}$. The benefits of operating as a public company constitute the costs of conducting business as a private company, and vice versa.

The issue of selecting the corporate ownership structure is widely discussed in the literature. The most significant benefits of operating as a public company include: benefits from risk diversification, liquidity of shares, or manager monitoring. The costs of operating as a public company are: any costs of separating ownership from control, costs of financial statements and auditing, costs of an increased disclosure of inside information that might reduce the company's competitive advantages. The most important studies discussing these issues include publications by such authors as Leland and Pyle ${ }^{18}$, Holmström and Tirole ${ }^{19}$,

\footnotetext{
${ }^{16}$ L. Zingales, Insider Ownership and the Decision to Go Public, "Review of Economic Studies", 1995, Vol. 62, pp. $425-448$

M. Pagano, F. Panetta, L. Zingales, Why Do Companies Go Public, "Journal of Finance" 1998, Vol. 53, pp. 27-64

${ }^{18} \mathrm{H}$. Leland, D. Pyle, Information Asymmetries, Financial Structure and Financial Intermediation, "Journal of Finance" 1977, Vol. 31, pp. 371-387
} 
Bolton and Von Thadden ${ }^{20}$, Amihud and Mendelson ${ }^{21}$, as well as Chemmanour and Fulghieri $^{22}$. Only a few publications take into account the possibility of changing and deferring a decision. A good example is the choice model put forward by S. Benninga, M. Helmantel and O. Sarig ${ }^{23}$.

The model discusses the case of an entrepreneur who considers the possibility of initial public offering. It is assumed that it is possible to reverse an earlier decision at any time. In order to focus exclusively on ownership structure selection, the model ignores the problem of investment diversification. The criterion for choosing an ownership structure is the company value determined on the basis of cash flows. Cash flow formation is represented with the use of a binomial tree. There is a fixed difference, $P B / r \quad(P B>0)$, between the flow volume in a private company and that in a public one. The difference reflects a present value of private benefits of control. Private benefits of control include both the value of control rights and agency cost savings resulting from the separation of ownership and control. In other words, $P B$ covers every difference between cash flows generated by a public and a private company. If we assume that cash flow $C F_{0}$ is a cash flow in period 0 , and its level does not depend on whether the company is public or private, then at any moment $t$ and state of reality $s$, flow $C F_{0} u^{s} d^{t-s}$ determines the stream of benefits when the company is public, while flow $C F_{0} u^{s} d^{t-s}$ $+P B$ determines benefits for a private company. Coefficient $u$ is a coefficient of a cash flow increase, and $d$ is a coefficient of a cash flow decrease $(u>1>d)$. Company valuation is made with the use of state price framework. The binomial model has two such prices: a price assuming a flow increase and a price assuming a flow decrease. The level of these prices depends on whether the company is private or public. Variables $q_{u}$ and $p_{u}$ stand for prices with the assumption that there is a cash flow increase in a public and a private company, respectively, while $q_{d}$ i $p_{d}$ indicate prices with the assumption of a cash flow decrease in a public and a private company, respectively. Since both an entrepreneur making a considerable outlay on a private company and an investor investing in a public company can also invest in risk-free assets, the following equation is satisfied:

\footnotetext{
${ }^{19}$ B. Holmström, J. Tirole, Market Liquidity and Performance Monitoring, "Journal of Political Economy” 1993, Vol. 101, pp. 678-709

${ }^{20}$ P. Bolton, E.L. Von Thadden, Blocks, Liquidity and Corporate Control, "Journal of Finance” 1998, Vol. 53, pp. $1-26$

${ }^{21}$ Y. Amihud, H. Mendelson, Liquidity and Asset Prices: Financial Management Implications, "Financial Management" 1998, Vol. 17, pp. 5-15

${ }^{22}$ T. Chemmanour, P. Fulghieri, A Theory of the Going Public Decision, "Review of Financial Studies" 1999, Vol. 12, pp. 249-280

${ }_{23}$ S. Benninga, M. Helmantel, O. Sarig, The Timing of Initial Public Offerings, "Journal of Financial Economics" 2005, Vol. 75, pp. 115 - 132
} 


$$
p_{u}+p_{d}=q_{u}+q_{d}=\frac{1}{1+r_{f}}
$$

In order to take into account incomplete portfolio diversification, which causes the entrepreneur to develop a stronger aversion to specific risk connected with the operation of his company, the model assumes that $p_{u}<q_{u}$ i $p_{d}>q_{d}$. Investors with well-diversified portfolios, i.e. those investing in public companies, will value uncertain cash flows at a higher level. Hence the value of a public company is expected to be higher than that of a private company.

The values of a private company and a public one are calculated by means of the following formulas:

$$
\begin{aligned}
& V^{\text {Privat }}(C F)=p_{u} \cdot[u \cdot C F+P B+V(u C F)]+p_{d} \cdot[d \cdot C F+P B+V(d C F)], \\
& V^{\text {Public }}(C F)=q_{u} \cdot[u \cdot C F+V(u C F)]+q_{d} \cdot[d \cdot C F+V(d C F)],
\end{aligned}
$$

where:

$V^{\text {Public }}(C F)$ - public company value, $V^{\text {Privat }}(C F)$ - private company value.

The general function describing company value $V(C F)$ assumes the following form:

$$
V(C F)=\max \left\lfloor V^{\text {Public }}(C F) ; V^{\text {Privat }}(C F)\right\rfloor,
$$


The function (7) value is illustrated in Figure1:

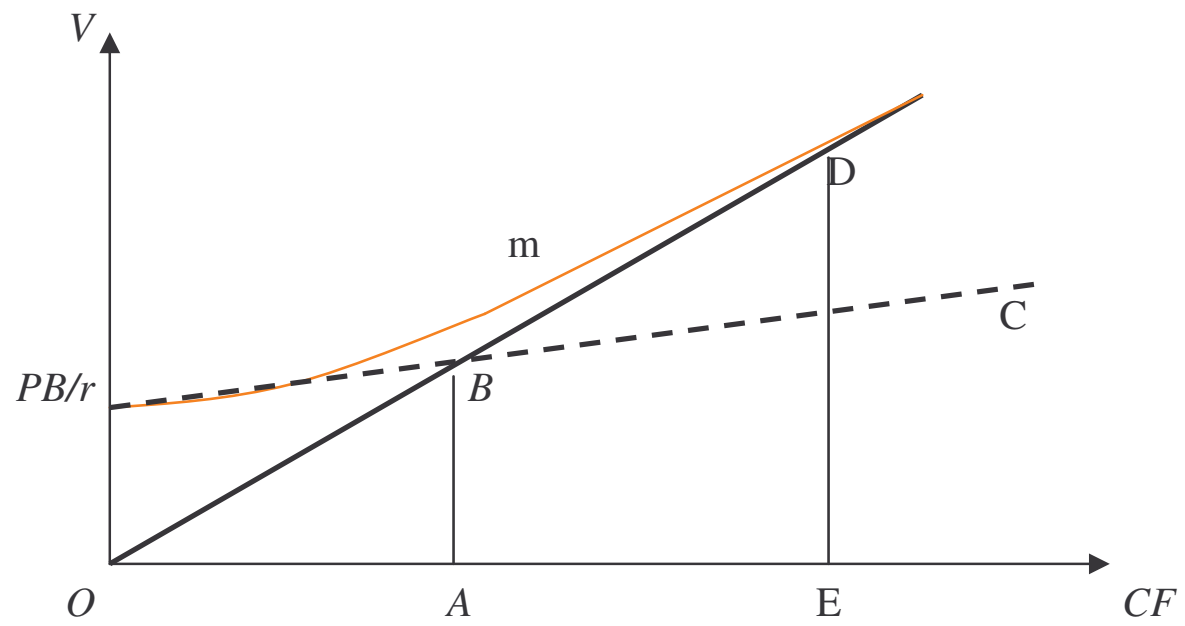

Fig. 1. Company value as a function of cash flow

Source: on the basis of S. Benninga, M. Helmantel, O. Sarig, The Timing of Initial Public Offerings, "Journal of Financial Economics" 2005, Vol. 75, pp. 115 - 132.

One can see that the graph illustrating the formation of the company value as a function of cash flow resembles a graph showing the value of a call option written for this flow ${ }^{24}$. Ray $P B / r C$ reflects private company value formation. Private company value formation in bracket $\angle P B / r ; \infty)$ is based on the assumption that the minimum level of benefits to be gained by the owner of a private company corresponds with the value of private benefits of control. Ray $O D$ illustrates public company value formation. Given flow level $O A$, the ownership structure is insignificant. This does not mean, however, that the ownership structure should be changed at this moment. We should take into account the possibility of such an increase or decrease in cash flow that would render the previously-taken decision unprofitable. Consequently, the possibility of deferring the decision to change ownership structure gains significance. Cash flow at level $O E$ is so high that if the firm operates as a private company, it is no longer worth deferring the decision to change the ownership structure into that of a public company. At point $E$, the public company value reaches the same level as a company value whose estimation considered the flexibility to change the ownership structure (point $D$ ). Using the language of financial option analysis, such a situation means that the total option value reaches the same level as the intrinsic value of the option. The shape of curve $m$ reflects the influence of the flexibility to change the ownership structure on the company value.

\footnotetext{
${ }^{24}$ Company value, illustrated in Figure 1, can be presented alternatively as the sum of public company value and put option value, reflecting the possibility of recovering private benefits of control.
} 
The right to choose the company ownership structure has a certain value. It seems that a good method of valuing this right is the option approach.

\section{Estimating the value of the right to choose the company ownership structure}

In our model of valuing private benefits of control, we will refer to the model put forward by Benninga, Helmantel and Sarig (BHS model). However, we calculate the company value in a different way from the BHS model. Each ownership structure is attributed a scenario concerning cash flow formation. In the case of a public company, it is scenario $A$; in the case of a private company - scenario $B$. The difference between these scenarios concerns the level and volatility $(\sigma)$ of the cash flow achieved by the owner. The possibility of specific risk diversification by a public company shareholder makes the volatility of the cash flows he achieves lower than the volatility of the flows achieved by a private company owner. A higher level of the cash flow achieved by a private company shareholder reflects private benefits of control in a given period.

Using a binomial model and assuming that the decision horizon is one period, Figure 2 presents the formation of the cash flow achieved by the owner, depending on the ownership structure.

\section{Scenario A Period 0}

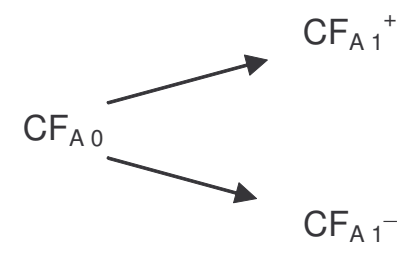

\section{Scenario B Period 0}

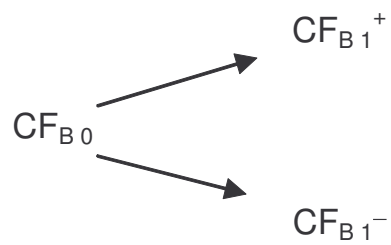

Fig. 2. Formation of cash flow values achieved by the owner, depending on the ownership structure

Source: own study.

Another difference between our proposal and the BHS model concerns the consideration of transaction costs connected with a change in the ownership structure. Transaction costs connected with the introduction of a company or its withdrawal from the stock exchange are treated as constants. We assume that the costs of withdrawing the company from the stock exchange are lower than the costs of a change in the opposite direction. 
The description of a decision situation presented here enables us to find an analogy between this situation and the situation of an option holder. An option to change the ownership structure can thus be categorized as a switch option. The occurrence of switch costs causes the option to become a compound option ${ }^{25}$. This is because the current decision to change the ownership structure, or the lack of it, has an impact on the structure in which the company will operate in future periods. As a consequence, it also influences the future costs of a change in the ownership structure (the exercise price of future options) and, as a result, future decisions to change the ownership structure. In the case of options to change the ownership structure, we talk of the occurrence of nested options. It follows from the above that underlying assets are the values of companies in particular scenarios ${ }^{26}$. The exercise price of an option in a given node is the value of a company in an appropriate node, in an alternative scenario, minus costs of switching from a given structure to an alternative structure.

The calculation of the company value with an option to change the ownership structure is made simultaneously, first assuming that the firm exists as a public company (scenario $A$ ), then assuming that it exists as a private company (scenario $B$ ). The valuation procedure is recurrent in character. We commence it by starting from possible company values at the last moment a change in the ownership structure, i.e. an option exercise, may occur. At this moment the company value corresponds with the higher of the two values: the company value in a given scenario and the company value in an alternative scenario, minus outlays connected with a structure change. The company value in state $s$ at moment $t-1$ can be determined on the basis of the company value in state $s+1$ and $s-1$, at moment $t$. State $s+1$ means that the company value has increased in relation to its value in state $s$, and state s- 1 means that the company value has decreased in relation to the value in state $s$. The formula showing the company value in state $s$, at moment $t$, with the assumption of operating in a given structure, $m(m=A$, or $m=B): V_{t-1}^{s}(m)$ is as follows ${ }^{27}$ :

$$
V_{t-1}^{s}(m)=\max _{i}\left\{C F_{t-1}^{s}(i)+\frac{\left[q \cdot V_{t}^{s+1}(i)+(1-q) \cdot V_{t}^{s-1}(i)\right]}{e^{r_{f}}}-I(m \rightarrow i)\right\}
$$

\footnotetext{
${ }^{25}$ N.Kulatilaka, L.Trigeorgis, The General Flexibility to Switch: Real Options Revisited, in: E.S. Schwartz, L. Trigeorgis, Real Options and Investment under Uncertainty, MIT Press, Cambridge 2001, pp.179-196.

${ }^{26}$ By company value we mean an appropriately defined sum of the present values of income earned by the owner at each node of the tree.

${ }^{27}$ N. Kulatilaka, L. Trigeorgis, op. cit.
} 
while hedging probabilities, $q$ and $1-q$ are given as the following formulas:

$q=\frac{e^{r_{f}}-d}{u-d}$,

$1-q=\frac{u-e^{r_{f}}}{u-d}$

where:

$C F_{t-1}^{s}(i)$ - flow achieved by the owner in the case of conducting business in the form of company $i$, in state $s$, at moment $t-1$,

$V_{t}^{s+1}(i), V_{t}^{s-1}(i)$ - company values at moment $t$, with the assumption that in relation to state $s$ there has been an increase (decrease) in the company value,

$I(m \rightarrow i)-$ costs of changing the company form; and if $m=1$, then $I(m \rightarrow i)=0$,

$r_{f}$ - interest rate of risk-free securities,

$u, d$-indicators of an increase and a decease in the company value, respectively.

The process of option valuation starts at the last moment $(N)$ the option can be exercised. At this moment the valuation formula takes the following form:

$V_{N}^{s}(m)=\max _{i}\left\{C F_{N}^{s}(i)-I(m \rightarrow i)\right\}$.

Let us examine the case of an investor who is considering the choice of an ownership structure for an undertaking he wants to implement. Let us assume that there are only two possible scenarios which simultaneously determine the choice of the ownership structure. We make an additional assumption that the decision horizon is one period. The formation of cash flow values, according to the two scenarios, is presented in Figure 3. 
Scenario A

Period 0

Period 1

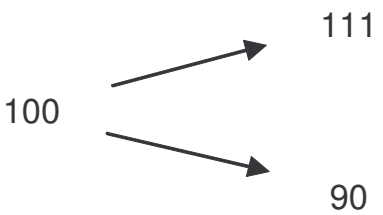

Scenario B

Period 0

Period 1

130

101

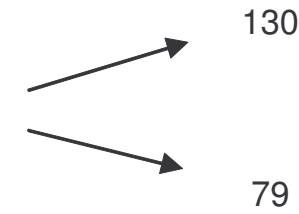

Fig. 3. Formation of cash flow values depending on the ownership structure

Source: own study

It has been established that the withdrawal of a company from the stock exchange involves the cost of 4 , whereas the introduction of a company into the stock exchange costs 8 . Figure 4 presents company value formation with the assumption of the flexibility to change the ownership structure. Company values have been estimated on the basis of formulas (8) (11).

\section{Scenario A}

Period 0

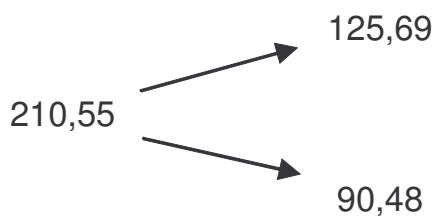

\section{Scenario B} Period 0

Period 1

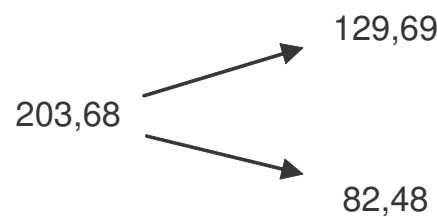

Fig. 4. Company value formation depending on the ownership structure Source: own study

It should be added that public and private company values estimated on the basis of discounted expected cash flows, i.e. without considering the possibility of changing the company form, are 200 and 202, respectively. The formula for estimating public and private company values taking into account the possibility of "switching" from one company form to the other, i.e. a change in the ownership structure, is as follows:

- for a public company:

$V_{0}(A)=P V(A)+F(A \rightarrow B)$,

- for a private company:

$$
V_{0}(B)=P V(B)+F(B \rightarrow A),
$$

and:

$V(F)=\max \left[V_{0}(A) ; V_{0}(B)\right]$, 
where:

$V_{0}(A), \quad V_{0}(B)$ - current value of a public and a private company, respectively, with the flexibility to change the company form from public into private and from private into public, $P V(A), P V(B)$ - current values of a public and a private company, respectively, without the flexibility to change the company form, $F(A \rightarrow B), F(B \rightarrow A)$ - value of flexibility to change from a public into a private company, with the assumption that the company operates as a public company, and from a private into a public company, with the assumption that the company operates as a private company, respectively.

Consequently, it is possible to establish the value of the right to change the ownership structure, with the assumption that the ownership structure chosen is optimal for the company value. The value of flexibility to change from a public to a private company, $F(A \rightarrow B)$, is given as the following formula:

$F(A \rightarrow B)=V(F)-P V(A)$,

whereas the value of the flexibility to change from a private to a public company, $F(B \rightarrow A)$, can be estimated on the basis of the formula below:

$F(B \rightarrow A)=V(F)-P V(B)$.

With reference to the example under consideration: $V_{0}(A)=210.5, V_{0}(B)=203.7$, hence: $V(F)=\max \left[V_{O}(A) ; V_{O}(B)\right]=210.5$. Consequently, in accordance with formula (15), the flexibility to change the ownership structure from a public to a private company is worth: 210.5- $200.00=10.5$, while the flexibility to change the ownership structure from a private to a public company (formula (16)) is worth $210.5-202.0=8.5$. In the light of the definition of control right which we have adopted, the amount of 10.5 can be treated as the value of a control right which is the flexibility to change the ownership structure from a public to a private company. The amount of 8.5 can be treated as the value of a control right which is the flexibility to change the ownership structure from a private to a public company. 


\section{Conclusions}

The State Treasury's retention of shares in companies which are being privatized may result in politicians gaining private benefits of control. Politicians enjoy these benefits at the expense of the State Treasury and private investors. To protect their interests effectively, we need to identify the manifestations of private benefits of control and measure their value.

More generally, the issue of having control of a company can be reduced to the issue of having the right to choose the ownership structure. Since the decision to change the ownership structure is nor irreversible, the choice of the ownership structure is not a consequence of a simple comparison of benefits and costs. To value the right to choose the ownership structure, we can use the option valuation model. The need to take into account transaction costs connected with a change in the ownership structure causes the option to become a compound option. A convenient way of valuing this option seems to be the option-to-switch model.

As the value of private benefits of control perceived as the right to choose the ownership structure may considerably exceed the value of these benefits when estimated on the basis of the difference in expected cash flows, it may turn out that any values of the benefits estimated so far are understated.

\section{REFERENCES}

Aghion P., Bolton P., An Incomplete Contract Approach to Financial Contracting, "Review of Economic Studies" 1992, Vol. 59.

Amihud Y., Mendelson H., Liquidity and Asset Prices: Financial Management Implications, "Financial Management" 1998, Vol. 17.

Barclay M., Holderness C., Private Benefit of Control of Public Corporations, "Journal of Financial Economics" 1989, Vol. 25.

Benninga S., Helmantel M., Sarig O., The Timing of Initial Public Offerings, "Journal of Financial Economics" 2005, Vol. 75.

Bolton P., Von Thadden E.L., Blocks, Liquidity and Corporate Control, "Journal of Finance" 1998, Vol. 53. Boycko M., Shleifer A., Vishny R.W., A Theory of Privatization, “Economic Journal”, 1996, Vol. 106 Chemmanour T., Fulghieri P., A Theory of the Going Public Decision, "Review of Financial Studies" 1999, Vol. 12.

Demsetz H., Lehn K., The Structure of Corporate Ownership: Causes and Consequences, "Journal of Political Economy "1985, Vol. 93.

Dyck A., Zingales L., Private Benefits of Control: An International Comparison, "Journal of Finance” 2004, Vol. 59.

Erhardt O., Nowak E., Private Benefits and Minority Shareholder Expropriation - Empirical Evidence from IPOs of German Family-Owned Firm, “CFS Working Paper” 2001, Vol. 10.

Harris M., Raviv A., Corporate Governance: Voting Rights and Majority Rules, "Journal of Financial Economics" 1998, Vol. 20. 
Holmen M., Hőgfeldt P., A Law and Finance Analysis of Initial Public Offerings, "Stockholm School of Economics Working Paper" 2000.

Holmström B., Tirole J., Market Liquidity and Performance Monitoring, "Journal of Political Economy” 1993, Vol. 101.

Jelic R., Briston R., Aussenegg W, The Choice of Privatization Method and the Financial Performance of Newly Privatized Firms in Transition Economies, “Journal of Business Finance and Accounting”, 2003, Vol. 30 (7 and 8),

Jensen M.C., Meckling W.H., Theory of the firm: managerial behavior, agency costs and ownership structure, "Journal of Financial Economics" 1976, Vol. 3.

Johnson S., La Porta R., Lopez-de-Silanes F., A. Shleifer, Tunneling, “American Economic Review”, 2000, Vol. 90.

Kulatilaka N., Trigeorgis L., The General Flexibility to Switch: Real Options Revisited, in: E.S. Schwartz, L. Trigeorgis, Real Options and Investment under Uncertainty, MIT Press, Cambridge 2001.

Leland H., Pyle D., Information Asymmetries, Financial Structure and Financial Intermediation, "Journal of Finance" 1977, Vol. 31.

Nenova T., The Value of Corporate Votes and Control Benefits: A Cross-country Analysis, "NBER Working Paper" 2000.

Pagano M., Panetta F., Zingales L., Why Do Companies Go Public, “Journal of Finance” 1998, Vol. 53.

Perotti E.C., Credible Privatization, American Economic Review, 1995, Vol. 85

Rydqvist K., Empirical Investigation of the Voting Premium, "Northwestern University Working Paper" 1987, Vol. 35.

Schindele I., Theory of Privatization in Eastern Europe: Literature Review, "Fondazione Eni Enrico Mattei", 2003

Shleifer A, Vishny R.W., Polticians and Firms, "Quarterly Journal of Economics ", 1994, Vol. 109

Zingales L., The Value of the Voting Right: A Study of the Milan Stock Exchange Experience, "Review of

Financial Studies" 1994, Vol. 7.

Zingales L., Insider Ownership and the Decision to Go Public, "Review of Economic Studies", 1995, Vol. 62

Zingales L., What Determines the Value of Corporate Votes, “Quarterly Journal of Economics” 1995, Vol. 110. 